\title{
IS A MODEL OF COMPREHENSIVE REGIONALISM TRADE- INCREASING FOR V4 COUNTRIES? SECTORAL APPROACH
}

\section{Iryna Gauger, Katarzyna Sledziewska*}

\begin{abstract}
This paper aims to identify the impact of a "deep" (economic union) and "shallow" (Common Commercial Policy) integration on 4 Visegrad countries' trade with the EU and non-EU industrialized countries. Trade flows are analysed on the basis of sectors over the period of 1995-2011: the gravity model also utilizes sectoral value-added and sectoral output as proxies for the market size. The impact of regional trade agreements (RTAs) is evaluated for 17 WIOD sectors based on the research methodology developed by Baldwin (2006), Flam and Nordstrom (2003) and Fernandes (2006). Contrary to the mentioned research studies, this paper uses a more advanced econometric technique - the Poisson pseudo-maximum-likelihood method displayed in Silva and Tenreyro (2006). This paper concludes that both "deep" and "shallow" trade arrangements have a more pronounced effect on Visegrad high value-added product exports than on Visegrad low value-added product exports. Common Commercial Policy's trade effects on RTAs, for instance in the case of Mexico and Turkey, are comparable to its trade effects with EU countries. The Common Commercial Policy's effect on RTAs is almost absent in low-value-added product sectors of Visegrad countries. Thus, we conclude that integration with the EU influenced Visegrad countries' trade of higher value-added goods with both the EU and non-EU industrialized countries.
\end{abstract}

Keywords: EU effect, FTA effect, regionalism, sectoral trade, Visegrad JEL Classification: F13, F15

\section{Introduction}

The Visegrad countries - Poland, the Czech Republic, Slovakia and Hungary - have transformed successfully their economies from a planned to market-based model, and integrated them into the European Union during last 25 years. External trade liberalization was an important part of the market reforms agenda of the 4 post-socialist countries, and had a goal of fostering economic modernization. Prior to the development of closer ties with the European Union, the countries have already had a free trade arrangement between them - the Central European Free Trade Agreement, which all 4 were required to exit before joining the EU. The integration between Visegrad countries prior to their EU entry was of a quite "shallow" nature: it did not go much further than the elimination of tariffs and reductions of non-tariff barriers. The integration of Visegrad countries into the EU led not only to the elimination of trade barriers with the EU

Iryna Gauger, University of Warsaw, Poland (irenas_ua@yahoo.com);

Katarzyna Sledziewska, University of Warsaw, Poland (k.sledziewska@uw.edu.pl). 
countries, but also to the common trade regulations that opened new possibilities for trade and investment with the rest of Eastern Europe. The EU integration represents the "deep" economic integration format in Eastern Europe, which can be compared to the "shallow" format of economic relations that CEFTA and CCE countries share with non-EU countries today.

In addition, trade analysis of CEE countries is absent for sectoral trade data. This paper makes an effort to close the gap in existing literature by dividing trade flows into 17 WIOD sectors, which allows the collection of evidence that displays sectoral value added and sectoral output. We are also interested in answering questions of economic development that Central and Eastern European countries currently face. Did participation in the EU's single market help modernize the EU and the rest of the world's structure of trade? Did it allow Visegrad countries to expand foreign sales of traditional international trade products or high value goods? These questions are discussed in this paper using the Poisson pseudolikelihood analysis of sectoral trade of Poland, the Czech Republic, Slovakia and Hungary between 1995-2011 as a basis.

\section{Regionalism and Visegrad Countries}

As regional cooperation issues grow to become the hottest policy topics in Europe, the effects of regionalism become an increasingly important field of research.

The motivation for the sectoral trade research of Visegrad countries can be attributed to Baldwin's research (Baldwin, 2014) and the WTO's research project (WTO, 2011). In his recent studies, Baldwin stresses the rise of supply-chain trade in international trade flows and the importance of the elimination of non-tariff barriers to foster intra-industry goods exchange. Non-tariff barriers to harmonization are especially the focus of deep and comprehensive free trade agreements among countries. One of the most successful agreements in this regard has been European Union Single Market programme that V4 countries have participated in since the early 2000s. Other examples of RTAs in the world economy have also featured the harmonization of sanitary and phyto-sanitary measures and technical standards. The WTO report deals precisely with the issue of "shallow" versus "deep" preferential agreements. The research study finds that the deeper the level of integration (more various features such as competition policy, non-tariff measures, intellectual property rights) an agreement includes, the greater countries trade with each other in parts and components. The gravity model, estimated using data from 200 countries between 1980 and 2007, found that preferential trade agreements increase trade in parts and components by 35 per cent among country members.

The research methodology draws from the literature on the analysis of exports panel data with the use of the gravity equation and dummy variables to identify the trade effects. The gravity research of bilateral total trade flows has been methodologically enhanced in numerous studies, from which we can distinguish the series by Anderson (1979), Bergstrand (1990), Markusen and Wigle (1990) and Leamer (1992).

The peculiarities of this empirical study is its use of sectoral indicators of the supply and demand side of the trade flow - sector-specific value-added - and supplication 
of the Poisson methodology to infer the results. The gravity model inherits a lot from the above-mentioned empirical studies of Flam and Nordstrom (2003), Baldwin et al. (2006), and Fernandes (2006).

Flam and Nordstrom (2003) analysed 9 trade sectors of 20 industrialized countries between 1995 and 2002. The model specification of Flam and Nordstrom's paper includes logs of the GDPs of exporting and importing countries, bilateral real exchange rates, average real exchange rates of the third countries against importing ones, country pair dummies, year dummies, and dummies for exports between the EU countries and between EU and non-EU states. The regression methodology included the effects of the OLS procedure. The study identified significant euro effects in the sectors with higher value added and nonstandardized products.

Fernandes (2006) utilized sectoral output of 25 Standard International Trade Classification (SITC, Rev.3) sectors in the gravity equation of trade. The author examined 21 countries during 1988-2003 with the use of estimation techniques such as simple fixed effects OLS, difference-GMM estimator, and system-GMM estimator. The dependent variable was real exports, while the independent variables included the exporter and importer sectoral value-added, lagged exports, the measure of exchange-rate volatility, real exchange rate, country-pair fixed effect, year dummies, exporter's and importer's dummies for intra-euro trade, dummy for trade from euro to non-euro country, and dummy for trade from non-euro to euro country. The author concluded that the industries with the highest degree of product processing were influenced by euro introduction.

Many studies find that Visegrad countries benefitted from EU integration indirectly apart from single market liberalization and trade and investment openness effects. Richter (2012) points out that in 2007 the value of aggregate intra-Visegrad trade was two and a half times higher than that of 2003. The rate of growth in these countries' trade with the 'old' EU member states was only $50 \%$ of intra-industry trade growth. The effects have been in place before the actual accession date - 2004. He found that firms involved in intraVisegrad trade may have gradually elaborated their new, geographically diversified sales/ procurement strategy.

In numerous studies related to the effects of EU integration, A. Jambor focussed on the EU Agricultural Policy implications for Visegrad countries. Jambor (2013) discussed that Visegrad countries' (V4) accession to the European Union in 2004 caused the intensity of the V4 agricultural food trade to increase significantly after the enlargement. In most cases, there was deterioration in the V4 agricultural food trade balance with the EU15. All analysed countries experienced a decline in their trade of processed goods, though the results were believed to be acceptable.

Akhvlediani and Sledziewska (2016) analysed, whether Common Commercial Policy was beneficial on the export performances of the V-4 countries and estimate the augmented gravity model by employing Poisson pseudo-maximum-likelihood (PPML) estimator for time periods before and after the EU accession, in 1999-2003 and 2004-2013, respectively. It was found that Common Commercial Policy and EU enlargement had positive impact on $\mathrm{V}-4$ export performances. 
Ambroziak (2011) analysed the impact of the foreign direct investment (FDI) on intraindustry trade (IIT) patterns in the V4 countries in the period of 1995-2008: The FDI has been a driving force of these countries' foreign trade, especially for the IIT. The theory and previous empirical studies show that the FDI has had a positive impact on vertical intraindustry trade (VIIT), while the influence of this variable on horizontal intra-industry trade (HIIT) is ambiguous. The results of the research argued that the FDI in the VCs stimulated not only VIIT, but also HIIT.

Brodzicki (2014) investigated whether the involvement of V4 economies since 1995 has become increasingly integrated in global value chains. On the one hand, they have imported more and more intermediate inputs for manufacturing industries. On the other, V4's participation in GVC production has steadily increased. Although some tendencies were common for all V4 countries, there were some significant differences. Firstly, the level of integration into the GVC varied: Poland is, at least to an extent, dependent on participation in GVC, with both imports and exports, while Hungary is the leader in both. The Czech Republic, Slovakia and Hungary managed to develop RCA in capital-intensive and high-tech industries. Conversely, Poland finds its competitive position in predominantly resource-based industries.

Attilla (2015) analysed country- and industry-specific determinants of HIIT and VIIT in agricultural food products between the Visegrad countries, (the Czech Republic, Hungary, Poland and the Slovak Republic) and the European Union in the period of 19992013. The results confirmed that IIT is mainly vertical in the Visegrad countries, though the majority of their exports consist of low quality/value-added agricultural food products to European markets. The results suggest that factor endowments and distance are mainly negatively related to IIT, while product differentiation was does not foster two-way trade of quality-differentiated goods. The study identified a negative relationship between productivity as well as foreign direct investment and IIT.

Zysk and Smiech (2014) found that FDI strongly influences the volume of Polish, Slovak and Czech exports and imports; only for Hungary does FDI not stimulate foreign trade. The value of imports and exports is correlated with the value of FDI inflow. As far as statistics are concerned, there is a significant inter-dependence between the inflow of FDI to V4 countries and the geographical and commodity pattern of their foreign trade.

According to Bartha (2014) the internationalization process of domestic companies of Visegrad countries was characterized by an outward development path - a heavy reliance on outside resources forces the domestic firms to face tough international competition, even in local markets. The government should help local enterprises in becoming more competitive, but success is highly questionable. Bartha and others (2014) have shown that three variables firm size, family ownership and innovation - had an $11.8 \%$ combined effect on the Small and Medium-Sized Enterprise Internationalisation Index of Visegrad SME enterprises.

Durendez and others' (2014) research project also examined the patterns of Visegrad companies' internationalization. A majority of firms started their internationalization efforts after the economic transformation, since most studies indicated that the firms' main targets was the EU. The traditional pathway of stages model of internationalization is dominant, 
however, nowadays firms go international earlier than before, often at the time of their establishment, or one or two years later. Most firms use exporting modes, especially direct exporting, as an initial stage of internalization.

Toporowski (2011) also confirmed that the trade of the Czech Republic, Hungary, Poland and Slovakia evolved significantly in terms of their product structures, witnessed by the growing high value added products intra-industry trade indices. The author detected that an important part of these changes took place even before the formal 2004 EU Eastern enlargement, which was proven with the econometric methods in this paper. Another interesting insight is the fact that between 1995 and 2012, intra-industry trade became more and more concentrated within a limited group of types of traded products.

The foreign direct investment, trade flows and internalization of enterprises is the main emphasis of studies in the context of V4 entry to EU post-entry transformation of their economies. The outlook of most available research studies is positive with regard to the "EU period" of Poland, the Czech Republic, Hungary and the Slovak Republic. Our research aims to add to the existing literature by giving special attention to two specific issues in Visegrad countries' international trade.

First, the previous studies focussed on the gross trade flows and inter-industry trade of Visegrad countries. This paper investigates the disaggregated trade at the industry level. In particular, we look at 17 manufacturing industries based on classification used in WIOD research projects. We are evaluating the impact of the EU membership on the sectoral trade of V4 countries and, thus, are discussing the difference between sectors. The similar research for the industrialized countries has been undertaken by Baldwin, Skudelny and Taglioni (2006). The authors used the gravity model and OLS methodology and applied it to sectoral trade flows. The study identified the significant impact of EMU on the increase in trade flows between industrialized countries. Similar research has been done by Flam and Nordstrom (2003), Lejour and Demooij (2004), Fernandes (2006). We also use the sectoral output data to proxy for the market size of sectoral trade in the gravity model. More specifically, the value added in each of 17 WIOD sectors is used, which had not been done before.

Second, we would like to distinguish between the EU's effect and RTA's (regional trade agreement) effects on the bilateral sectoral trade flows of Visegrad countries. The study follows the inspiration of WTO research published in the WTO World Trade Report 2011. The WTO report discussed the trade effect differences between "deep" and "shallow' integration. The "deep" free trade area consists of additional features that facilitate trade - non-tariff barriers reduction, intellectual property rights protection and so on. "Shallow" integration does not go that deep and concentrates on tariff reduction and customs rules harmonization. In the context of Visegrad countries, "deep" integration is represented by the EU membership, which includes all the features of free movement of goods and services. Visegrad countries have "shallow" integration arrangements with industrialized countries outside of the European Union - South Korea, Mexico, and Turkey.

Therefore, the hypotheses of the study is that the EU integration increases trade, especially in "increasing returns and imperfect competition" industries (as in Baldin et al., 2006). Moreover, the EU effect is stronger than PTA effect. 
The next section will explain the methodology of the research based on the similar studies of the sectoral trade.

\section{Methodology}

The gravity equation is commonly used to measure different effects of trade. In the standard gravity model, we assume that the economic power of trading partners (measured as GDP) and trade costs (measured as the distance between them) are the key variables to explain the volume of trade. The first theoretical application of the gravity equation was presented by Helpman (1987). Helpman's theorem proclaims that the volume of trade relative to GDP will be proportional to the relative size of countries. Helpman's work can explain the encouraged expectations that bigger and similar-sized countries tend to trade more intensely with each other than the smaller and different-sized ones. Based on these expectations, the more elaborate versions of the gravity equation for years have been representing "the workhorse for empirical studies" in international economics (Eichengreen and Irwin, 1997) and have been responsible for the eruption of empirical works.

The attractiveness of the empirical applications of the model stems from the possibility of obtaining a transparent answer to the most important questions about the determinants of bilateral trade. Gravity models are recognized for their strong fit to the data and the possibility to test a variety of hypothesis by adding proxies of trade costs. For example, in order to evaluate the trade effect of economic integrations, dummy variables for membership in a particular agreement can be added, which allows to study the trade potential associated with integration.

In the traditional version of a gravity model, value of export is a function of bilateral trade for a pair of countries, their GDPs and the distance between them.

$$
\ln X_{i j}^{t}=\beta_{0}+\beta_{1} \ln \left(G D P_{i}^{t}\right)+\beta_{2} \ln \left(G D P_{j}^{t}\right)+\beta_{3} \ln \left|G D P p c_{i}^{t}-G D P p c_{j}^{t}\right|+\beta_{4} \ln \operatorname{dist}_{i j}+\varepsilon_{i j}^{t}
$$

- $\quad X_{i j}^{t}$ exports from country $i$ do $j$, time $t$

- $\quad G D P_{i}^{t}$ nominal GDP of country $i$

- $\quad G D P_{j}^{t}$ nominal GDP of country $j$

- $\quad\left|G D P p c_{i}^{t}-G D P p c_{j}^{t}\right|$ difference of GDP per capita between $i$ and $j$

- $\quad$ dist $_{i j}$ distance between country $i$ and $j$.

Recently, researchers demonstrated that the gravity equation can be derived from a variety of theoretical models based on neoclassical or monopolistic competition approaches for homogenous and differentiated goods with the representation of the role of technology, factor endowments or demand differences.

A series of articles, including those by Anderson (1979), Bergstrand (1985, 1989), Helpman and Krugman (1985), Deardoff (1998), Anderson and van Wincoop (2001) Eaton and Kortum (2001), and the recent work of CieSlik (2010) have provided the theoretical background for this popular tool for measuring trade effects. Anderson (1979) presented a theoretical foundation for the gravity model based on constant elasticity of substitution (CES) preferences and goods that are differentiated by the region of origin. 
In order to include the specialization effect, Bergstrand $(1989,1990)$ and Deardoff $(1998)$ preserved the CES preference structure and added monopolistic competition, or a HecksherOhlin structure. Anderson and Wincoop (2001) provided the theoretical explanation of how borders impact trade. Bergstrand (1989) was the first to derive the gravity equation, including per capita incomes, as independent variables. Cieslik (2010) presented the theoretical derivation for the role of factor proportions in the gravity equation.

Anderson's and Wincoop's (2001) approach is applied to determine the effect of other institutions, such as currency unions, on bilateral trade and to enter them into the gravity model. However, not much theoretical work has been done on monetary integration, in which dummy variables were used in gravity models. Nonetheless, these are applied by various researchers (beginning with the first work of Rose, 2000). A common finding in the literature is that there is an impact of monetary integration that can be evaluated by applying the gravity model.

The focus of our paper is the sectoral trade of Visegrad countries, and sector classification is the one used in World Input-Output Database research. The list of the available sectors is presented in the Appendix. The sectoral exports was created on the basis of 6-digit HS classification exports of countries participating in the research. With the use of the WIOD conversion table, the HS 6-digit trade from Comtrade and WITS databases was summarized into 17 sectors trade for all country pairs of our research study (see Appendix).

We classify exports of 4 Visegrad countries with 40 countries (all EU countries, except for Croatia, USA, Canada, Brazil, Mexico, Russia, Turkey, Australia, Japan, South Korea, China, India, Indonesia, Taiwan). The list of the countries is limited to the countries participating in the WIOD project, as we can make use of sectoral output and value added indicators for 17 sectors reported by the WIOD project statistics which is available online WIOD (2011). The countries sample contains both EU countries, and other major industrialized countries - NAFTA, developed and emerging countries from Asia, Russia and Turkey as European semi-periphery.

The data is available for the years between 1995 and 2011. The tariff values also originate from WITS database, where the information at the 6-digit level was aggregated into 17 WIOD sectors and average tariffs by merging the data according to the correspondence table and summarized across the WIOD sectors. The sectoral output data - value-added and demand - are taken from the WIOD database available online. Data on distance, contiguity and common language is supplied by CEPII. The World Bank Indicators Database is the source of real GDP per capita.

Apart from EU impact on exports of Visegrad countries, the effect of PTAs will be analysed in the study. PTA is the preferential trade agreement between two countries about substantial trade liberalization. In our study we distinguish between agricultural PTAs (FTAAs) and industrial PTAs (FTAIs). Moreover, we classify them into shallow and deep integration groups. So as 4 format of PTAs will be analysed: agricultural PTAs with SPS harmonization, agricultural PTAs without SPS harmonization, industrial PTAs with technical barriers to trade regulation and industrial PTAs without technical barriers to trade regulation. 
Table 1 | Explanation Expected Sign and Source of Variables in the Regression Model

\begin{tabular}{|c|c|c|c|}
\hline Variable & Explanation & Source & Expected sign \\
\hline Exp & $\begin{array}{l}\text { Logarithm of value of exports of Reporter to } \\
\text { Partner }\end{array}$ & $\begin{array}{l}\text { WITS/ } \\
\text { Comtrade }\end{array}$ & \\
\hline tariff & $\begin{array}{l}\text { Logarithm of the Average tariff of the partner } \\
\text { in the corresponding sector } \\
\ln (1+\text { tariff/100) }\end{array}$ & WITS & $\begin{array}{l}\text { Higher tariff in partner country } \\
\text { is related to lower exports }\end{array}$ \\
\hline VA_reporter & $\begin{array}{l}\text { Logarithm of value added in the WIOD sector } \\
\text { of the reporter }\end{array}$ & WIOD & $\begin{array}{l}\text { Higher value added } \\
\text { in the corresponding industry } \\
\text { of exporter (supply side) } \\
\text { corresponds to the higher } \\
\text { exports }\end{array}$ \\
\hline demandPar & $\begin{array}{l}\text { Logarithm of the expression (Value } \\
\text { added of the plus imports minus exports } \\
\text { in the corresponding sector) of the importer }\end{array}$ & WIOD & $\begin{array}{l}\text { Higher demand } \\
\text { in the corresponding WIOD } \\
\text { industry of importer is related to } \\
\text { higher imports }\end{array}$ \\
\hline contig & $\begin{array}{l}\text { Dummy variable equal to } 1 \text { if countries are } \\
\text { contiguous }\end{array}$ & CEPII & $\begin{array}{l}\text { Adjacent countries are expected } \\
\text { to trade more }\end{array}$ \\
\hline ngdp_rep & Nominal GDP of exporter & World Bank & $\begin{array}{l}\text { Higher GDP in the exporter } \\
\text { is related to higher } \\
\text { production and exports }\end{array}$ \\
\hline$n g d p \_p a r$ & Nominal GDP of importer & World Bank & $\begin{array}{l}\text { Higher GDP in the importer } \\
\text { is related to higher demand } \\
\text { and correspondingly to higher } \\
\text { imports }\end{array}$ \\
\hline d_rgdpc & $\begin{array}{l}\text { Logarithm of absolute value of the difference } \\
\text { between real GDP per capita of the exporter } \\
\text { and importer (In ( abs|rgdpc_rep-rgdpc_ } \\
\text { par|)) }\end{array}$ & World Bank & $\begin{array}{l}\text { Similar in terms of capital-labour } \\
\text { endowment countries are } \\
\text { trading more }\end{array}$ \\
\hline$E U$ & $\begin{array}{l}\text { Dummy variable equal to } 1 \text { if both countries } \\
\text { belong to } \mathrm{EU} \text { in the corresponding year }\end{array}$ & & $\begin{array}{l}\text { Joint EU membership is } \\
\text { expected to raise trade }\end{array}$ \\
\hline FTAAwSPS & $\begin{array}{l}\text { Dummy if both countries liberalized trade } \\
\text { in agricultural products and harmonized SPS } \\
\text { measures at the same time }\end{array}$ & WTO & $\begin{array}{l}\text { FTA in agricultural products with } \\
\text { SPS harmonization is expected } \\
\text { to raise trade in } 1 \text { and } 3 \text { sector }\end{array}$ \\
\hline FTAIWTBT & $\begin{array}{l}\text { Dummy if both countries liberalized trade } \\
\text { in manufactures and affirmed rights and } \\
\text { obligations on TBT, harmonized regulations } \\
\text { and signed mutual recognition agreements }\end{array}$ & WTO & $\begin{array}{l}\text { FTA in industrial products with } \\
\text { TBT obligations is expected to } \\
\text { raise trade in sectors } 2 \text {, and } 4 \\
\text { through } 17\end{array}$ \\
\hline FTAAwSPS & $\begin{array}{l}\text { Dummy variable equal to } 1 \text { if countries } \\
\text { liberalized trade in agricultural products but } \\
\text { don't have harmonization of SPS measures }\end{array}$ & WTO & $\begin{array}{l}\text { FTA in agricultural products } \\
\text { without SPS harmonization is } \\
\text { expected to raise trade in } 1 \text { and } \\
3 \text { sector, but to a lesser extent } \\
\text { than in the previous case }\end{array}$ \\
\hline FTAIWTBT & $\begin{array}{l}\text { Dummy variable equal to } 1 \text { if countries } \\
\text { liberalized trade in manufactures but do not } \\
\text { have harmonization of TBT regulations }\end{array}$ & WTO & $\begin{array}{l}\text { FTA in industrial products with } \\
\text { no TBT obligations is expected } \\
\text { to raise trade in sectors } 2 \text {, and } 4 \\
\text { through } 17, \text { but to a lesser extent }\end{array}$ \\
\hline
\end{tabular}

Source: Authors' calculations

Following the regression model analyses of Baldwin et al., (2006) we build the model of exports of reporter $(i)$ to partner $(j)$ in WIOD sector $k$ in period $t$ and include a number of gravity model independent variables together with dummies responsible for EU integration and PTAs concluded between countries (Figure 2): 


$$
\begin{aligned}
& E_{X X} P_{i j k t}=\beta_{0}+\beta_{1} \text { VA }_{i k t}+\beta_{2} \text { Demand }_{j k t}+\beta_{3} \text { Tariff }_{i j k t}+\beta_{4} \text { DGDPp }_{i j t}+\beta_{5} \text { Cont }_{i j}+\beta_{6} d_{-} \text {rgdpc }+ \\
& \beta_{7} \text { EU }_{i j t}+\beta_{8} \text { FTAAwSPS }_{i j t}+\beta_{9} \text { FTAIwTBT }_{i j t}+\beta_{10} \text { FTAAnSPS }_{i j t}+\beta_{11} \text { FTAInTBT }_{i j t}+\beta_{12} \text { Year }_{t}+ \\
& +\beta_{13} \text { Countrypair }_{i j k}+\varepsilon_{i j k t}
\end{aligned}
$$

Year $_{t}$ is time dummy variable to take account of bilateral pair invariant tome-specific effects, Countrypair $_{i j k}$ - country pair and sector specific dummy variable, $e_{i j k t}$ - error term.

Applying the Poisson pseudo-maximum-likelihood (PPML) method, we escape the heteroskedastic characteristics of gravity model log-linearized problems, as argued by Silva and Tenreyro (2006). The gravity model is already a commonly accepted and a standard tool to estimate determinants of trade flow. However, the specification of the gravity equation for estimation purposes differs according to the approaches of different authors. The most remarkably, Silva and Tenreyro (2006) argued, that the logarithmic transformation of the original model is not relevant approach to estimate elasticities. They provide a profound explanation why the typically applied solution that consists in taking the logarithms and then estimating the resulting equation with some form of a linear least squares estimator is statistically incorrect and leads to inconsistent estimates. Following their recommendations, we applied the Poisson pseudo-maximum likelihood estimator.

We have panel data for 17 years and 40 by 40 country pairs. Following Baldwin et al. (2006) we check for specific country pair and industry fixed effects, as well as for the year effects. We have time-series data for exports, sectoral value-added, nominal GDPs and real GDPs per capita. The non-stationary variables are tariffs. There are dummy variables controlling for contingency, the EU membership, participation in PTAs.

\section{Empirical Results}

The regression model estimated for each of the product sectors and the results are presented in Tables A.2 and A.3. First of all, the proxies for the supply and demand side of sectoral exports have significant explanatory power in our model. The coefficients of the variables VA reporter and demandPar are in all cases positive and statistically significant. The output of the exporters has a particularly positive correlation with exports in sectors such as "Agriculture," "Mining," "Food," "Wood," "Chemicals," "Rubber," "Basic metals," and "Electricity." The relationship between exports and demand in the sector is particularly strong in sectors such as "Textiles," "Rubber," "Non-metallic products," "Machinery," "Electrical equipment," and "Transport equipment."

Coefficients of the Tariff variable of an importer's tariff level demonstrate a negative and statistically significant sign in all sectors except for agriculture suggesting that tariff protection lowers the flow of goods into the country. The positive and statistically significant sign of the Tariff variable of agricultural exports might mean that exports of agricultural products are insensitive to tariff measures and more dependent on policies towards agriculture within countries (like the Common Agricultural Policy).

Being a neighbour increases the exports of all types of commodities analysed. The difference in GDP per capita has a statistically significant and negative effect on exports 
in all cases except for "Coke," "Chemicals," and "Electrical equipment." This means that a low ratio of the per capita of a given exporter to the per capita income of an importer increases the bilateral export flow in the sector. Especially, this relation is strong in sectors such as "Manufacturing goods," "Wood products," and "Textiles." The sectors of more sophisticated goods are less dependent of capital-labour difference between the countries. This fact can lead to the conclusion that the difference in the capital-labour ratio, as proposed by Heckscher-Olin theorem, has a lesser impact on higher value-added sectors.

Participation in regional trade agreements plays a significant part in the export development of Visegrad countries, just as our results suggest. The estimation results resonate with the conclusions of the previous studies discussed in the literature review.

EU integration had a significant impact on V4 export development between 1995 and 2011 in every sector that the regression exercise analysed.

The results for the Visegrad countries show a substantial positive EU effect for all sectors, excluding "Mining," "Coke," "Basic metals," and "Electrical equipment." The strongest positive effects of EU integration are found for sectors such as "Agriculture," "Food," "Pulp and Paper," "Leather," "Rubber," "Machinery," and "Electrical machinery". The EU trade arrangements have a pronounced effect on trade in higher-value added products in Visegrad countries in comparison to the situation for all 40 countries where EU effects concentrate in basic sectors (Nasadiuk and Sledziewska, 2016).

Apart from trade within the EU, Visegrad countries have preferential trade arrangements with other industrialized countries, for example Mexico and Turkey, which fall into Common Commercial Policy. The trade effects of cooperation with the countries, that Visegrad countries have simple regional trade agreements with, are comparable to the trade effects they have in trade with EU countries (Table 2). All industrial RTAs include TBT regulation harmonization, so we cannot argue whether "deep" or simple RTA in industrial products works better for Poland, Hungary, the Slovak Republic, and the Czech Republic. What we can observe is that the coefficient of the FTA dummy is positive for "Chemicals," "Rubber," "Basic metals," "Machinery," "Electrical equipment," "Transport equipment," "Other manufacturing," higher value added products, and sectors characterized by imperfect competition and increasing returns to scale. The RTAs effect is almost absent in the low value-added products sectors of Visegrad countries; the only positive effect is found in the sector "Textiles".

RTA with SPS measures harmonization had a negative effect on the exports of agricultural products and food. The impact of shallow agricultural PTA is actually positive for the food industry.

For Visegrad countries, on the contrary, positive EU and RTA with technical barriers regulation effects are attributed to higher value added products and sectors characterized by imperfect competition and increasing returns to scale.

The robustness check of our benchmark estimations is undertaken by estimating the gravity model, where sectoral output and demand are substituted by the nominal GDP of the exporter and importer. The change of proxies for the market size in the gravity regression does not have a substantial impact on the GDP, difference in capital-labour ratio, tariffs, or integration dummies on the results (A). 
Table 2 | Effects of the EU and Simple and "Deep" PTAs on Sectoral Exports, Visegrad Countries

\begin{tabular}{|l|c|c|c|c|c|c|}
\hline \multirow{2}{*}{} & \multicolumn{2}{|c|}{ EU effect } & \multicolumn{2}{c|}{$\begin{array}{c}\text { FTA with standards } \\
\text { harmonization }\end{array}$} & \multicolumn{2}{c|}{$\begin{array}{c}\text { FTA without standards } \\
\text { harmonization }\end{array}$} \\
\hline Agriculture & 1.342 & $(13.24)^{* *}$ & -2.777 & $(5.34)^{* *}$ & 0.224 & -0.55 \\
\hline Mining & 0.286 & $(3.17)^{* *}$ & -0.171 & -0.37 & - & - \\
\hline Food & 1.329 & $(14.38)^{* *}$ & -1.289 & $(5.77)^{* *}$ & 0.953 & $(3.23)^{* *}$ \\
\hline Textiles & 0.125 & -1.6 & 0.7 & $(3.43)^{* *}$ & - & - \\
\hline Leather & 1.223 & $(7.12)^{* *}$ & -0.989 & $(7.14)^{* *}$ & - & - \\
\hline Wood & 0.874 & $(10.12)^{* *}$ & 0.115 & -0.49 & - & - \\
\hline Pulp and paper & 1.58 & $(14.66)^{* *}$ & -0.054 & -0.25 & - & - \\
\hline Coke & 1.063 & $(7.06)^{* *}$ & -0.755 & -1.82 & - & - \\
\hline Chemicals & 1.132 & $(13.12)^{* *}$ & 0.35 & $(2.04)^{*}$ & - & - \\
\hline Rubber & 1.687 & $(14.23)^{* *}$ & 0.818 & $(4.67)^{* *}$ & - & - \\
\hline Non-metallic & 0.868 & $(9.66)^{* *}$ & -0.075 & -0.66 & - & - \\
\hline Basic metals & 1.046 & $(12.66)^{* *}$ & 0.714 & $(4.15)^{* *}$ & - & - \\
\hline Machinery & 1.315 & $(11.26)^{* *}$ & 0.837 & $(6.28)^{* *}$ & - & - \\
\hline Electrical & 1.77 & $(15.84)^{* *}$ & 1.405 & $(10.51)^{* *}$ & - & - \\
\hline Transport & 1.279 & $(10.49)^{* *}$ & 1.403 & $(7.13)^{* *}$ & - & - \\
\hline Manufacturing & 0.948 & $(8.07)^{* *}$ & 0.871 & $(6.19)^{* *}$ & - & - \\
\hline Electricity & 1.424 & $(4.56)^{* *}$ & - & - & - & - \\
\hline
\end{tabular}

Source: Authors' calculations

\section{Conclusions}

The added value of our study to existing literature on Visegrad countries primarily includes our results on comprehensive regionalism's impact on the sectoral trade of V4 countries. We are particularly interested in the EU integration's impact and the impact of RTAs of V4 countries with 40 industrialized countries. Moreover, the study compares the effects of EU integration and RTA liberalization on VA exports and identifies the sectors influenced most by both formats of external liberalization by Visegrad countries.

The article deals with the analysis of the impact of regionalism on disaggregated exports of 4 Visegrad countries in 1995-2011 years. The available economic literature suggests that the impact of the EU integration was positive for V4 countries in terms of export growth, FDI inflow, the change of exports structure toward sophistication, and the increase in vertical intra-industry trade. The results of our study go in line with the literature on the EU integration of V4 countries. The specific feature of this paper is that sectoral exports are analysed for 17 WIOD sectors, from "Agriculture" to "Electricity". We follow the research 
methodology of Baldwin (2006), Flam and Nordstrom (2003), Fernandes (2006), and Silva and Tenreyro (2006). The results show substantial and positive EU effects on all sectors, excluding "Mining," "Coke," "Basic metals," and "Electrical equipment." The strongest positive effects of the EU integration are found for sectors such as "Agriculture," "Food," "Pulp and Paper," "Leather," "Rubber," "Machinery," and "Electrical machinery." This means that the EU trade arrangements have a more pronounced effect on the trade of rather higher-value added products than the trade of basic products in Visegrad countries.

The specific contribution of our study is the identification of the impact of deeper integration with the EU countries and RTA integration with non-EU industrialized countries on sectoral trade over the period of 1995-2011. Apart from trade within the EU, Visegrad countries have regional trade arrangements with other industrialized countries. The estimated coefficients show that the effects of Visegrad countries regional trade agreements are comparable to the trade effects V4 countries have in trade with the EU countries. We can observe that the coefficient at the RTA dummy is positive for "Chemicals," "Rubber," "Basic metals," "Machinery," "Electrical equipment," "Transport equipment," "Other manufacturing," higher value added products, and sectors characterized by imperfect competition and increasing returns to scale. The RTAs effect is almost absent in the low value-added products sectors of Visegrad countries; the only positive effect is found in the "Textiles" sector.

The main key finding is that the modernization of Visegrad countries as a consequence of EU integration helped them 1) improve their own export performance in trade with the EU countries (exports of high value added products grew quicker), 2) improve their export performance with the rest of industrialized countries (as exports of high value-added goods increased).

Based on the research, the following policy recommendations can be made. First, the free movement of goods and services increases trade and welfare. Thus, economic union policies within the EU are important. Second, common regulations are important for trade. The "deepening" of arrangements regulating international trade is beneficial for the welfare of Visegrad countries and, potentially, for other countries, which would prefer to switch from a "shallow" to a "deep" mode of integration.

The results of the trade effects of Visegrad country exports resonate with the conclusions of previous research of sectoral trade (Baldwin, 2006; Flam and Nordstrom, 2003, and Fernandes, 2006): integration effects are larger for sectors with imperfect competition and increasing returns characteristic, and with intra-industry possibilities.

The study also confirmed the positive effect on the high value-added trade of Visegrad countries together with the work of Brodzicki (2014) and Toporowski (2011).

It leads us to conclude that regional trade agreements are beneficial when they deal with non-tariff trade barriers. The Visegrad countries have been long involved in "deep" integration processes in the European Union engaging in substantial trade barriers reduction and institutional harmonization. This mode of regional cooperation helped them perform better in trade cooperation with other industrialized countries. Thus, our results imply that countries with the necessity to develop their production and export structure are recommended to choose a "deep" model of regionalism, as it brings them closer to their development goals. 


\section{Appendix}

WIOD Export Sectors Classification

\begin{tabular}{|l|l|}
\hline WIOD sector & \multicolumn{1}{|c|}{ Name of WIOD sector } \\
\hline $\mathbf{1}$ & Agriculture, hunting, forestry and fishing \\
\hline $\mathbf{2}$ & Mining and quarrying \\
\hline $\mathbf{3}$ & Food, beverages and tobacco \\
\hline $\mathbf{4}$ & Textiles and textiles products \\
\hline $\mathbf{5}$ & Leather and footwear \\
\hline $\mathbf{6}$ & Wood and products of wood and cork \\
\hline $\mathbf{7}$ & Pulp, paper, printing and publishing \\
\hline $\mathbf{8}$ & Coke, refined petroleum and nuclear fuel \\
\hline $\mathbf{9}$ & Chemicals and chemical products \\
\hline $\mathbf{1 0}$ & Rubber and plastics \\
\hline $\mathbf{1 1}$ & Other non-metallic mineral \\
\hline $\mathbf{1 2}$ & Basic metals and fabricated metals \\
\hline $\mathbf{1 3}$ & Machinery \\
\hline $\mathbf{1 4}$ & Electrical and optical equipment \\
\hline $\mathbf{1 5}$ & Transport equipment \\
\hline $\mathbf{1 6}$ & Manufacturing, recycling \\
\hline $\mathbf{1 7}$ & Electricity, gas and water supply \\
\hline
\end{tabular}

Source: WIOD project (www.wiod.org) 
Effects of PTAs on Sectoral Exports, 4 Visegrad Countries

\begin{tabular}{|c|c|c|c|c|c|c|c|c|}
\hline $\begin{array}{l}\text { WIOD } \\
\text { sector }\end{array}$ & $\begin{array}{l}\text { Agri- } \\
\text { culture }\end{array}$ & Mining & Food & Textiles & Leather & Wood & $\begin{array}{l}\text { Pulp and } \\
\text { Paper }\end{array}$ & Coke \\
\hline tariff & $\begin{array}{l}2.291 \\
(5.01)^{* *}\end{array}$ & $\begin{array}{r}-30.959 \\
(4.38)^{* *}\end{array}$ & $\begin{array}{l}-1.876 \\
(4.03)^{* *}\end{array}$ & $\begin{array}{c}-15.817 \\
(12.16)^{* *}\end{array}$ & $\begin{array}{l}-8.282 \\
(6.75)^{* *}\end{array}$ & $\begin{array}{l}-8.506 \\
(3.14)^{* *}\end{array}$ & $\begin{array}{l}5.523 \\
(3.03)^{* *}\end{array}$ & $\begin{array}{l}-5.953 \\
-1.03\end{array}$ \\
\hline VAreporter & $\begin{array}{l}0.401 \\
(11.50)^{* *}\end{array}$ & $\begin{array}{c}0.473 \\
(13.79)^{* *}\end{array}$ & $\begin{array}{c}0.577 \\
(16.63)^{* *}\end{array}$ & $\begin{array}{c}0.27 \\
(7.00)^{* *}\end{array}$ & $\begin{array}{l}0.101 \\
(2.63)^{* *}\end{array}$ & $\begin{array}{c}0.424 \\
(10.49)^{* *}\end{array}$ & $\begin{array}{c}0.348 \\
(11.75)^{* *}\end{array}$ & $\begin{array}{l}0.125 \\
(3.54)^{* *}\end{array}$ \\
\hline demandPar & $\begin{array}{c}0.402 \\
(12.98)^{* *}\end{array}$ & $\begin{array}{l}0.073 \\
(2.17)^{*}\end{array}$ & $\begin{array}{c}0.41 \\
(15.75)^{* *}\end{array}$ & $\begin{array}{c}0.56 \\
(18.60)^{* *}\end{array}$ & $\begin{array}{l}0.532 \\
(9.37)^{* *}\end{array}$ & $\begin{array}{c}0.367 \\
(14.14)^{* *}\end{array}$ & $\begin{array}{c}0.408 \\
(15.77)^{* *}\end{array}$ & $\begin{array}{l}0.139 \\
(2.58)^{* *}\end{array}$ \\
\hline contig & $\begin{array}{c}2.093 \\
(24.57)^{* *}\end{array}$ & $\begin{array}{c}2.733 \\
(29.33)^{* *}\end{array}$ & $\begin{array}{c}1.943 \\
(26.20)^{* *}\end{array}$ & $\begin{array}{c}2.074 \\
(26.35)^{* *}\end{array}$ & $\begin{array}{c}1.539 \\
(13.42)^{* *}\end{array}$ & $\begin{array}{c}2.286 \\
(30.68)^{* *}\end{array}$ & $\begin{array}{l}2.235 \\
(29.14)^{* *}\end{array}$ & $\begin{array}{c}2.843 \\
(23.59)^{*}\end{array}$ \\
\hline d_rgdpc & $\begin{array}{c}-0.28 \\
(7.05)^{* *}\end{array}$ & $\begin{array}{l}-0.503 \\
(6.96)^{* *}\end{array}$ & $\begin{array}{l}-0.259 \\
(6.17)^{* *}\end{array}$ & $\begin{array}{c}-0.562 \\
(11.27)^{* *}\end{array}$ & $\begin{array}{c}-0.475 \\
(11.15)^{* *}\end{array}$ & $\begin{array}{c}-0.703 \\
(13.15)^{* *}\end{array}$ & $\begin{array}{c}-0.24 \\
(5.87)^{* *}\end{array}$ & $\begin{array}{l}-0.092 \\
-1.1\end{array}$ \\
\hline EU & $\begin{array}{c}1.342 \\
(13.24)^{* *}\end{array}$ & $\begin{array}{l}0.286 \\
(3.17)^{* *}\end{array}$ & $\begin{array}{c}1.329 \\
(14.38)^{* *}\end{array}$ & $\begin{array}{l}0.125 \\
-1.6\end{array}$ & $\begin{array}{l}1.223 \\
(7.12)^{* *}\end{array}$ & $\begin{array}{c}0.874 \\
(10.12)^{* *}\end{array}$ & $\begin{array}{c}1.58 \\
(14.66)^{* *}\end{array}$ & $\begin{array}{l}1.063 \\
(7.06)^{* *}\end{array}$ \\
\hline FTAAwSPS & $\begin{array}{l}-2.777 \\
(5.34)^{* *}\end{array}$ & - & $\begin{array}{c}-1.289 \\
(5.77)^{* *}\end{array}$ & - & - & - & - & - \\
\hline FTAAnSPS & $\begin{array}{l}0.224 \\
-0.55\end{array}$ & - & $\begin{array}{c}0.953 \\
(3.23)^{* *}\end{array}$ & - & - & - & - & - \\
\hline FTAIWTBT & - & $\begin{array}{l}-0.171 \\
-0.37\end{array}$ & - & $\begin{array}{c}0.7 \\
(3.43)^{* *}\end{array}$ & $\begin{array}{c}-0.989 \\
(7.14)^{* *}\end{array}$ & $\begin{array}{l}0.115 \\
-0.49\end{array}$ & $\begin{array}{l}-0.054 \\
-0.25\end{array}$ & $\begin{array}{l}-0.755 \\
-1.82\end{array}$ \\
\hline _cons & $\begin{array}{l}-2.666 \\
(2.87)^{* *}\end{array}$ & $\begin{array}{l}3.688 \\
(4.51)^{* *}\end{array}$ & $\begin{array}{c}-5.437 \\
(5.71)^{* *}\end{array}$ & $\begin{array}{l}-1.013 \\
-1.35\end{array}$ & $\begin{array}{l}2.076 \\
(2.11)^{*}\end{array}$ & $\begin{array}{l}-1.157 \\
-1.47\end{array}$ & $\begin{array}{l}-0.88 \\
-1.23\end{array}$ & $\begin{array}{l}9.989 \\
(6.45)^{* *}\end{array}$ \\
\hline R2 & 0.52 & 0.56 & 0.71 & 0.75 & 0.35 & 0.77 & 0.73 & 0.42 \\
\hline $\mathbf{N}$ & 1,986 & 1,657 & 1,985 & 1,980 & 1,866 & 1,746 & 1,975 & 1,260 \\
\hline
\end{tabular}

Source: Authors' calculations 
The Effects of PTAs on Sectoral Exports (continued), 4 Visegrad Countries

\begin{tabular}{|c|c|c|c|c|c|c|c|c|c|}
\hline WIOD sector & $\begin{array}{l}\text { Chemi- } \\
\text { cals }\end{array}$ & Rubber & $\begin{array}{c}\text { Non- } \\
\text { metallic }\end{array}$ & $\begin{array}{l}\text { Basic } \\
\text { metals }\end{array}$ & $\begin{array}{l}\text { Machin- } \\
\text { ery }\end{array}$ & $\begin{array}{c}\text { Electri- } \\
\text { cal }\end{array}$ & $\begin{array}{c}\text { Trans- } \\
\text { port }\end{array}$ & $\begin{array}{c}\text { Manufac- } \\
\text { turing }\end{array}$ & $\begin{array}{l}\text { Electri- } \\
\text { city }\end{array}$ \\
\hline tariff & $\begin{array}{l}-4.982 \\
(2.59)^{* *}\end{array}$ & $\begin{array}{c}-6.552 \\
(3.05)^{* *}\end{array}$ & $\begin{array}{c}-5.883 \\
(4.28)^{* *}\end{array}$ & $\begin{array}{r}-11.541 \\
(6.93)^{* *}\end{array}$ & $\begin{array}{l}-3.686 \\
(2.27)^{*}\end{array}$ & $\begin{array}{c}-5.729 \\
(3.20)^{* *}\end{array}$ & $\begin{array}{c}-8.278 \\
(5.03)^{* *}\end{array}$ & $\begin{array}{l}-9.99 \\
(4.16)^{* *}\end{array}$ & $\begin{array}{r}-80.001 \\
(3.94)^{* *}\end{array}$ \\
\hline VAreporter & $\begin{array}{c}0.403 \\
(15.21)^{* *}\end{array}$ & $\begin{array}{c}0.4 \\
(11.40)^{* *}\end{array}$ & $\begin{array}{l}0.317 \\
(8.47)^{* *}\end{array}$ & $\begin{array}{c}0.416 \\
(12.20)^{* *}\end{array}$ & $\begin{array}{l}0.452 \\
(11.03)^{* *}\end{array}$ & $\begin{array}{c}0.385 \\
(11.29)^{* *}\end{array}$ & $\begin{array}{l}0.164 \\
(3.12)^{* *}\end{array}$ & $\begin{array}{c}0.535 \\
(10.60)^{* *}\end{array}$ & $\begin{array}{l}0.809 \\
(4.68)^{* *}\end{array}$ \\
\hline demandPar & $\begin{array}{c}0.402 \\
(15.84) * *\end{array}$ & $\begin{array}{c}0.542 \\
(16.96)^{* *}\end{array}$ & $\begin{array}{l}0.524 \\
(17.18)^{* *}\end{array}$ & $\begin{array}{c}0.492 \\
(21.44)^{* *}\end{array}$ & $\begin{array}{l}0.551 \\
(17.29)^{* *}\end{array}$ & $\begin{array}{c}0.56 \\
(18.79)^{* *}\end{array}$ & $\begin{array}{c}0.528 \\
(13.07)^{* *}\end{array}$ & $\begin{array}{c}0.496 \\
(17.51)^{* *}\end{array}$ & $\begin{array}{c}0.241 \\
(2.06)^{*}\end{array}$ \\
\hline contig & $\begin{array}{c}1.715 \\
(25.05)^{* * *}\end{array}$ & $\begin{array}{c}1.8 \\
(24.26)^{* * *}\end{array}$ & $\begin{array}{c}1.885 \\
(27.81)^{* *}\end{array}$ & $\begin{array}{c}2.062 \\
(33.99) * *\end{array}$ & $\begin{array}{c}1.78 \\
(14.17)^{* *}\end{array}$ & $\begin{array}{c}1.143 \\
(12.79)^{* *}\end{array}$ & $\begin{array}{c}1.2 \\
(10.77)^{* *}\end{array}$ & $\begin{array}{c}2.135 \\
(24.32)^{* *}\end{array}$ & $\begin{array}{c}1.813 \\
(8.24)^{* *}\end{array}$ \\
\hline d_rgdpc & $\begin{array}{l}-0.032 \\
-0.88\end{array}$ & $\begin{array}{l}-0.213 \\
(5.67)^{* *}\end{array}$ & $\begin{array}{l}-0.289 \\
(7.63)^{* *}\end{array}$ & $\begin{array}{l}-0.164 \\
(4.05)^{* *}\end{array}$ & $\begin{array}{l}-0.404 \\
(7.43)^{* *}\end{array}$ & $\begin{array}{l}-0.266 \\
(6.91)^{* *}\end{array}$ & $\begin{array}{l}-0.07 \\
-1.38\end{array}$ & $\begin{array}{c}-0.795 \\
(13.53)^{* *}\end{array}$ & $\begin{array}{c}-0.029 \\
-0.19\end{array}$ \\
\hline$E U$ & $\begin{array}{c}1.132 \\
(13.12)^{* *}\end{array}$ & $\begin{array}{c}1.687 \\
(14.23)^{* *}\end{array}$ & $\begin{array}{l}0.868 \\
(9.66)^{* *}\end{array}$ & $\begin{array}{c}1.046 \\
(12.66)^{* *}\end{array}$ & $\begin{array}{c}1.315 \\
(11.26)^{* *}\end{array}$ & $\begin{array}{c}1.77 \\
(15.84)^{* *}\end{array}$ & $\begin{array}{c}1.279 \\
(10.49)^{* *}\end{array}$ & $\begin{array}{l}0.948 \\
(8.07)^{* *}\end{array}$ & $\begin{array}{l}1.424 \\
(4.56)^{* *}\end{array}$ \\
\hline FTAAwSPS & - & - & $\begin{array}{l}- \\
-\end{array}$ & $\begin{array}{l}- \\
-\end{array}$ & $\begin{array}{l}- \\
-\end{array}$ & $\begin{array}{l}- \\
-\end{array}$ & $\begin{array}{l}- \\
-\end{array}$ & - & - \\
\hline FTAAnSPS & - & - & - & - & - & - & - & - & - \\
\hline FTAIwTBT & $\begin{array}{c}0.35 \\
(2.04)^{*}\end{array}$ & $\begin{array}{c}0.818 \\
(4.67)^{* *}\end{array}$ & $\begin{array}{l}-0.075 \\
-0.66\end{array}$ & $\begin{array}{l}0.714 \\
(4.15)^{* *}\end{array}$ & $\begin{array}{c}0.837 \\
(6.28)^{* *}\end{array}$ & $\begin{array}{c}1.405 \\
(10.51)^{* *}\end{array}$ & $\begin{array}{l}1.403 \\
(7.13)^{* *}\end{array}$ & $\begin{array}{l}0.871 \\
(6.19)^{* *}\end{array}$ & $\begin{array}{c}-4.425 \\
(10.18)^{* *}\end{array}$ \\
\hline _cons & $\begin{array}{l}-0.424 \\
-0.56\end{array}$ & $\begin{array}{l}-3.999 \\
(5.57)^{* *}\end{array}$ & $\begin{array}{l}-2.093 \\
(2.71)^{* *}\end{array}$ & $\begin{array}{l}-2.815 \\
(3.94)^{* *}\end{array}$ & $\begin{array}{r}-5.042 \\
(4.85)^{* *}\end{array}$ & $\begin{array}{l}-3.163 \\
(3.83)^{* *}\end{array}$ & $\begin{array}{l}2.794 \\
(2.88)^{* *}\end{array}$ & $\begin{array}{c}-5.946 \\
(6.67)^{* *}\end{array}$ & $\begin{array}{l}-8.32 \\
(2.06)^{*}\end{array}$ \\
\hline R2 & 0.59 & 0.78 & 0.65 & 0.83 & 0.41 & 0.65 & 0.31 & 0.79 & 0.27 \\
\hline $\mathbf{N}$ & 2,031 & 1,997 & 1,994 & 2,030 & 1,988 & 1,893 & 1,624 & 1,856 & 236 \\
\hline
\end{tabular}

Note: ${ }^{*} p<0.05 ;{ }^{* *} p<0.01$

Source: Authors' calculations 
The Effects of PTAs on Sectoral Exports, Visegrad Countries (nominal GDP as the proxy for the market size)

\begin{tabular}{|c|c|c|c|c|c|c|c|c|}
\hline & $\begin{array}{l}\text { Agri- } \\
\text { culture }\end{array}$ & Mining & Food & Textiles & Leather & Wood & $\begin{array}{c}\text { Pulp and } \\
\text { Paper }\end{array}$ & Coke \\
\hline I_tariff & $\begin{array}{c}1.709 \\
(4.42)^{* *}\end{array}$ & $\begin{array}{l}11.992 \\
-1.93\end{array}$ & $\begin{array}{l}-0.986 \\
(3.66)^{* *}\end{array}$ & $\begin{array}{l}-17.084 \\
(16.15)^{* *}\end{array}$ & $\begin{array}{c}-12.812 \\
(7.20)^{* *}\end{array}$ & $\begin{array}{r}-14.104 \\
(7.76)^{* *}\end{array}$ & $\begin{array}{l}-5.255 \\
(5.29)^{* *}\end{array}$ & $\begin{array}{c}-3.258 \\
-1.12\end{array}$ \\
\hline I_ngdp_rep & $\begin{array}{c}0.428 \\
(16.28)^{* *}\end{array}$ & $\begin{array}{l}0.693 \\
(12.54)^{* * *}\end{array}$ & $\begin{array}{c}0.727 \\
(26.15)^{* *}\end{array}$ & $\begin{array}{c}0.633 \\
(21.88)^{* *}\end{array}$ & $\begin{array}{c}0.466 \\
(10.52)^{* *}\end{array}$ & $\begin{array}{c}0.52 \\
(16.96)^{* *}\end{array}$ & $\begin{array}{c}0.574 \\
(24.76)^{* *}\end{array}$ & $\begin{array}{c}0.178 \\
(2.90)^{* *}\end{array}$ \\
\hline I_ngdp_par & $\begin{array}{c}0.356 \\
(16.44)^{* *}\end{array}$ & $\begin{array}{l}-0.195 \\
(2.92)^{* *}\end{array}$ & $\begin{array}{l}0.396 \\
(20.63)^{* *}\end{array}$ & $\begin{array}{l}0.534 \\
(24.25)^{* *}\end{array}$ & $\begin{array}{c}0.506 \\
(11.00)^{* *}\end{array}$ & $\begin{array}{l}0.398 \\
(23.11)^{* *}\end{array}$ & $\begin{array}{l}0.462 \\
(24.11)^{* *}\end{array}$ & $\begin{array}{c}0.119 \\
(3.59)^{* *}\end{array}$ \\
\hline contig & $\begin{array}{c}1.915 \\
(26.68)^{* *}\end{array}$ & $\begin{array}{l}2.648 \\
(9.29)^{* *}\end{array}$ & $\begin{array}{c}1.836 \\
(29.08)^{* *}\end{array}$ & $\begin{array}{l}1.804 \\
(26.68)^{* *}\end{array}$ & $\begin{array}{c}1.3 \\
(13.67)^{* *}\end{array}$ & $\begin{array}{c}2.163 \\
(32.41)^{* *}\end{array}$ & $\begin{array}{c}2.118 \\
(36.48)^{* *}\end{array}$ & $\begin{array}{c}2.626 \\
(25.14)^{* *}\end{array}$ \\
\hline I_d_rgdpc & $\begin{array}{c}-0.078 \\
(2.43)^{*}\end{array}$ & $\begin{array}{l}-0.954 \\
(9.95)^{* *}\end{array}$ & $\begin{array}{l}-0.092 \\
(3.05)^{* *}\end{array}$ & $\begin{array}{l}-0.073 \\
(2.00)^{*}\end{array}$ & $\begin{array}{l}0.036 \\
-0.55\end{array}$ & $\begin{array}{c}-0.38 \\
(10.94)^{* *}\end{array}$ & $\begin{array}{l}0.246 \\
(7.94)^{* *}\end{array}$ & $\begin{array}{l}-0.041 \\
-0.65\end{array}$ \\
\hline$E U$ & $\begin{array}{c}1.024 \\
(12.73)^{* *}\end{array}$ & $\begin{array}{l}-0.531 \\
(2.82)^{* *}\end{array}$ & $\begin{array}{c}1.133 \\
(15.23)^{* *}\end{array}$ & $\begin{array}{l}-0.699 \\
(11.08)^{* *}\end{array}$ & $\begin{array}{l}-0.088 \\
-0.86\end{array}$ & $\begin{array}{l}0.226 \\
(3.26)^{* *}\end{array}$ & $\begin{array}{c}0.799 \\
(11.01)^{* *}\end{array}$ & $\begin{array}{l}0.878 \\
(8.05)^{* *}\end{array}$ \\
\hline FTAAwSPS & $\begin{array}{l}-3.075 \\
(5.86)^{* *}\end{array}$ & - & $\begin{array}{l}-1.497 \\
(6.57)^{* *}\end{array}$ & - & - & - & - & - \\
\hline FTAAnSPS & $\begin{array}{r}0.278 \\
-0.67\end{array}$ & $\begin{array}{l}- \\
-\end{array}$ & $\begin{array}{r}0.384 \\
-1.32\end{array}$ & - & - & - & $\begin{array}{l}- \\
-\end{array}$ & - \\
\hline FTAIwTBT & - & $\begin{array}{l}-1.26 \\
(2.27)^{*}\end{array}$ & - & $\begin{array}{c}0.12 \\
-0.67\end{array}$ & $\begin{array}{l}-2.342 \\
(17.81)^{* *}\end{array}$ & $\begin{array}{l}-0.746 \\
(3.98)^{* *}\end{array}$ & $\begin{array}{l}-0.881 \\
(5.66)^{* *}\end{array}$ & $\begin{array}{l}-1.185 \\
(2.95)^{* *}\end{array}$ \\
\hline _cons & $\begin{array}{l}-4.522 \\
(5.22)^{* *}\end{array}$ & $\begin{array}{l}3.151 \\
-1.45\end{array}$ & $\begin{array}{l}-12.36 \\
(12.51)^{* *}\end{array}$ & $\begin{array}{l}-12.468 \\
(14.83)^{* *}\end{array}$ & $\begin{array}{l}-8.975 \\
(7.92)^{* *}\end{array}$ & $\begin{array}{l}-7.864 \\
(8.80)^{* *}\end{array}$ & $\begin{array}{l}-10.493 \\
(13.30)^{* *}\end{array}$ & $\begin{array}{l}8.175 \\
(4.29)^{* *}\end{array}$ \\
\hline $\mathbf{R 2}$ & 0.53 & 0.13 & 0.73 & 0.73 & 0.31 & 0.78 & 0.77 & 0.37 \\
\hline $\mathbf{N}$ & 2,310 & 1,968 & 2,419 & 2,469 & 2,312 & 2,254 & 2,430 & 1,751 \\
\hline
\end{tabular}

Source: Authors' calculations 
The Effects of PTAs on Sectoral Exports (continued), Visegrad Countries (nominal GDP as the proxy for the market size)

\begin{tabular}{|c|c|c|c|c|c|c|c|c|c|}
\hline & $\begin{array}{l}\text { Chemi- } \\
\text { cals }\end{array}$ & Rubber & $\begin{array}{c}\text { Non- } \\
\text { metallic }\end{array}$ & $\begin{array}{l}\text { Basic } \\
\text { metals }\end{array}$ & $\begin{array}{l}\text { Machin- } \\
\text { ery }\end{array}$ & $\begin{array}{l}\text { Electri- } \\
\text { cal }\end{array}$ & $\begin{array}{l}\text { Trans- } \\
\text { port }\end{array}$ & $\begin{array}{c}\text { Manufac- } \\
\text { turing }\end{array}$ & $\begin{array}{c}\text { Electri- } \\
\text { city }\end{array}$ \\
\hline I_tariff & $\begin{array}{c}-14.994 \\
(13.11)^{* *}\end{array}$ & $\begin{array}{l}-12.816 \\
(12.80)^{* *}\end{array}$ & $\begin{array}{l}-11.327 \\
(12.50)^{* *}\end{array}$ & $\begin{array}{l}-15.203 \\
(15.58)^{* *}\end{array}$ & $\begin{array}{l}-14.815 \\
(12.70)^{* *}\end{array}$ & $\begin{array}{r}-10.646 \\
(9.05)^{* *}\end{array}$ & $\begin{array}{c}-11.057 \\
(9.79)^{* *}\end{array}$ & $\begin{array}{l}-10.51 \\
(9.17)^{* *}\end{array}$ & $\begin{array}{r}-65.108 \\
(3.45)^{* *}\end{array}$ \\
\hline I_ngdp_rep & $\begin{array}{c}0.617 \\
(34.64)^{* *}\end{array}$ & $\begin{array}{c}0.697 \\
(27.03)^{* *}\end{array}$ & $\begin{array}{c}0.505 \\
(21.51)^{* *}\end{array}$ & $\begin{array}{c}0.555 \\
(21.52)^{* *}\end{array}$ & $\begin{array}{c}0.681 \\
(23.83)^{* *}\end{array}$ & $\begin{array}{c}0.555 \\
(18.52)^{* *}\end{array}$ & $\begin{array}{c}0.583 \\
(17.01)^{* *}\end{array}$ & $\begin{array}{c}0.786 \\
(25.79)^{* *}\end{array}$ & $\begin{array}{l}0.549 \\
(4.43)^{* *}\end{array}$ \\
\hline I_ngdp_par & $\begin{array}{c}0.464 \\
(30.90)^{* *}\end{array}$ & $\begin{array}{c}0.571 \\
(26.47)^{* *}\end{array}$ & $\begin{array}{c}0.536 \\
(30.40)^{* *}\end{array}$ & $\begin{array}{c}0.546 \\
(29.26)^{* *}\end{array}$ & $\begin{array}{c}0.671 \\
(26.29)^{* *}\end{array}$ & $\begin{array}{c}0.652 \\
(25.72)^{* *}\end{array}$ & $\begin{array}{c}0.737 \\
(27.30)^{* *}\end{array}$ & $\begin{array}{c}0.558 \\
(30.64)^{* *}\end{array}$ & $\begin{array}{l}0.192 \\
-1.69\end{array}$ \\
\hline contig & $\begin{array}{c}1.581 \\
(34.88)^{* *}\end{array}$ & $\begin{array}{c}1.826 \\
(28.86)^{* *}\end{array}$ & $\begin{array}{c}1.862 \\
(32.41)^{* *}\end{array}$ & $\begin{array}{c}2.053 \\
(36.93)^{* *}\end{array}$ & $\begin{array}{c}1.598 \\
(18.73)^{* *}\end{array}$ & $\begin{array}{c}1.174 \\
(13.53)^{* *}\end{array}$ & $\begin{array}{c}1.245 \\
(15.97)^{* *}\end{array}$ & $\begin{array}{c}2.053 \\
(27.22)^{* *}\end{array}$ & $\begin{array}{c}1.862 \\
(8.46)^{* *}\end{array}$ \\
\hline I_d_rgdpc & $\begin{array}{c}0.413 \\
(18.80)^{* *}\end{array}$ & $\begin{array}{c}0.287 \\
(10.34)^{* *}\end{array}$ & $\begin{array}{c}0.16 \\
(6.75)^{* *}\end{array}$ & $\begin{array}{l}0.173 \\
(6.19)^{* *}\end{array}$ & $\begin{array}{c}0.316 \\
(10.45)^{* *}\end{array}$ & $\begin{array}{l}0.186 \\
(6.41)^{* *}\end{array}$ & $\begin{array}{c}0.333 \\
(9.49)^{* *}\end{array}$ & $\begin{array}{c}-0.421 \\
(10.25)^{* *}\end{array}$ & $\begin{array}{c}-0.104 \\
-0.75\end{array}$ \\
\hline$E U$ & $\begin{array}{c}0.537 \\
(10.43)^{* *}\end{array}$ & $\begin{array}{c}0.896 \\
(12.07)^{* *}\end{array}$ & $\begin{array}{c}0.16 \\
(2.60)^{* *}\end{array}$ & $\begin{array}{c}0.674 \\
(10.45)^{* *}\end{array}$ & $\begin{array}{l}0.662 \\
(7.15)^{* *}\end{array}$ & $\begin{array}{c}1.267 \\
(13.69)^{* *}\end{array}$ & $\begin{array}{c}1.178 \\
(10.70)^{* *}\end{array}$ & $\begin{array}{l}0.431 \\
(5.01)^{* *}\end{array}$ & $\begin{array}{l}2.021 \\
(5.68)^{* *}\end{array}$ \\
\hline FTAAwSPS & - & - & - & - & - & - & - & - & $\begin{array}{l}- \\
-\end{array}$ \\
\hline FTAAnSPS & - & $\begin{array}{l}- \\
-\end{array}$ & - & $\begin{array}{l}- \\
-\end{array}$ & $\begin{array}{l}- \\
-\end{array}$ & $\begin{array}{l}- \\
-\end{array}$ & $\begin{array}{l}- \\
-\end{array}$ & - & - \\
\hline FTAIwTBT & $\begin{array}{l}-0.042 \\
-0.29\end{array}$ & $\begin{array}{l}0.023 \\
-0.21\end{array}$ & $\begin{array}{l}-0.698 \\
(7.61)^{* *}\end{array}$ & $\begin{array}{l}0.158 \\
-1.08\end{array}$ & $\begin{array}{l}-0.125 \\
-1.58\end{array}$ & $\begin{array}{c}0.473 \\
(3.96)^{* *}\end{array}$ & $\begin{array}{l}0.381 \\
(2.14)^{*}\end{array}$ & $\begin{array}{l}-0.325 \\
(3.37)^{* *}\end{array}$ & $\begin{array}{l}-3.582 \\
(8.92)^{* *}\end{array}$ \\
\hline _cons & $\begin{array}{c}-10.194 \\
(16.60)^{* *}\end{array}$ & $\begin{array}{c}-15.96 \\
(20.89)^{* *}\end{array}$ & $\begin{array}{l}-10.414 \\
(13.48)^{* *}\end{array}$ & $\begin{array}{l}-10.727 \\
(13.00)^{* *}\end{array}$ & $\begin{array}{c}-17.302 \\
(17.33)^{* *}\end{array}$ & $\begin{array}{l}-13.006 \\
(12.55)^{* *}\end{array}$ & $\begin{array}{l}-16.139 \\
(15.47)^{* *}\end{array}$ & $\begin{array}{l}-18.457 \\
(21.06)^{* *}\end{array}$ & $\begin{array}{c}-4.473 \\
-1.04\end{array}$ \\
\hline R2 & 0.75 & 0.77 & 0.7 & 0.8 & 0.62 & 0.56 & 0.61 & 0.82 & 0.23 \\
\hline $\mathbf{N}$ & 2,486 & 2,450 & 2,361 & 2,442 & 2,415 & 2,422 & 2,338 & 2,448 & 251 \\
\hline
\end{tabular}

Source: Authors' calculations 


\section{References}

Akhvlediani, T., Sledziewska, K. (2016). The Impacts of Common Commercial Policy on Export Performances of Visegrad Countries. Prague Economic Papers. Forthcoming, https://doi. org/10.18267/j.pep.593

Anderson, J. (1979). The Theoretical Foundation for the Gravity Equation. American Economic Review, 69(1), 106-116.

Ambroziak, L. (2011). FDI and Intra-Industry Trade: Theory and Empirical Evidence from the Visegrad Countries. International Journal of Economics and Business Research, 4(1-2), 180-198, https://doi.org/10.1504/ijebr.2012.044252

Attila, J. A. (2015). Country-and Industry-Specific Determinants of Intra-Industry Trade in AgriFood Products in the Visegrad Countries. Studies in Agricultural Economics, 117(2), 93-101, https://doi.org/10.7896/j.1514

Baldwin, R., Taglioni, D. (2006). Gravity for Dummies and Dummies for Gravity Equations. National Bureau of Economic Research, Inc. Cambridge Working Papers No. 12516, https://doi. org/10.3386/w12516

Baldwin, R., Skudelny, F., Taglioni, D. (2005). Trade Effects of the Euro: Evidence from Sectoral Data. European Central Bank. ECB Working Paper No. 446.

Baldwin, R. (2014). WTO 2.0: Governance of 21 st Century Trade. Review of International Organizations, 9(2), 261-283, https://doi.org/10.1007/s11558-014-9186-4

Bergstrand, J. H. (1990). The Heckscher-Olin-Samuelson Model, the Linder Hypothesis and the Determinants of Bilateral Intra-industry Trade. Economic Journal, 100(403), 1216-1229, https://doi.org/10.2307/2233969

Bartha, Z., Gubik, A. S. (2014). The Outward Focused Development Path in the Visegrad Countries in D. Kiendl-Wendner and K. Wach K. eds., International Competitiveness in Visegrad Countries: Macro and Micro Perspective. Graz: Fachhochschule Joanneym.

Bartha, Z., Gubik, A. S. (2014). SME Internalisation Index (SMINI) Based on the Sample of the Visegrad Countries in Gubik, A.S., Wach, K. (eds), International Entrepreneurship and Corporate Growth in Visegrad Countries. Mickolc: University of Miskolc, pp. 23-40.

Brodzicki, T. (2011). Structural Adjustments in Trade Relations of the Visegrad Group Countries. Paper presented at the the ETSG Thirteen annual conference.

Durendez, A., Wach, K. (eds.) (2014). Patterns of Business Internationalisation in Visegrad Countries - In Search for Regional Specifics. Cartagena: Universidad Politécnica de Cartagena. ISBN 978-84-942562-0-2.

Fernandes A. (2006). Trade Dynamics and the Euro Effect: Sector and Country Estimates. University of Essex and IPVC. Unpublished.

Flam, H., Nordstrom, H. (2003). Trade Volume Effects of the Euro: Aggregate and Sector Estimates. Institute for International Economic Studies. Unpublished.

Greenaway, D., Milner, C. (2002). Regionalism and Gravity. Scottish Journal of Political Economy, 49(5), 574-585, https://doi.org/10.1111/1467-9485.00249

Jambor, A. (2013). Comparative Advantages and Specialisation of the Visegrad Countries Agri-Food Trade. Acta Oeconomica et Informatica, 16(1), 22-34, https://doi.org/10.15414/ raae.2013.16.01.22-34

Leamer, E. E. (1992). Wage Effects of a U.S.-Mexican Free Trade Agreement. National Bureau of Economic Research. Working Paper No. 3991, https://doi.org/10.3386/w3991

Markusen, J. R., Wigle, R. M. (1990). Explaining the Volume of North-South Trade. Economic Journal, 100(403), 1206-1215, https://doi.org/10.2307/2233968 
Leamer, Edward E. (1992). Testing Trade Theory. National Bureau of Economic Research. NBER Working Papers No. 3957, https://doi.org/10.3386/w3957

Nasadiuk I., Sledziewska K. How Does Regional Integration Among Countries Influence Trade. Does the Impact Differ among Countries? Argumenta Oekonomika. Manual submitted.

Richter, S. (2012). Changes in the Structure of Intra-Visegrad Trade after the Visegrad Countries. Accession to the European Union (No. 5). The Vienna Institute for International Economic Studies.

Silva, S., Tenreyro S. (2006). The Log of Gravity. The Review of Economics and Statistics, 88(4), 641-658, https://doi.org/10.1162/rest.88.4.641

Silva, S., Tenreyro S. (2011). Further Simulation Evidence on the Performance of the Poisson Pseudo-Maximum Likelihood Estimator. Economics Letters, 112(2), 220-222, https://doi.org/10.1016/j.econlet.2011.05.008

Smiech, S., Zysk, W. (2014). The Influence of Foreign Direct Investment on Foreign Trade in the Visegrad Countries from 2001 to 2011. Entrepreneurial Business and Economics Review, 2(3), 7-18, https://doi.org/10.15678/eber.2014.020302

Toporowski, P. E. (2013). The Steps of Visegrad Countries towards Better Integration within the EU: a Case of Intra-industry Trade. Retrieved: http://www.etsg.org/ETSG2013/Papers/379.pdf

WIOD (2011) World Input-Output Database Retrieved: http://www.wiod.org/new_site/home.htm

WTO (2011). The WTO and Preferential Trade Agreements: From Co-Existence to Coherence. World Trade Report, Retrieved: https://www.wto.org/english/res_e/publications_e/ wtr11_e.htm 